\title{
Application of WeChat Teaching Platform in Interactive Translation Teaching
}

\author{
http://dx.doi.org/10.3991/ijet.v11i09.6113 \\ Zijuan Shi, Gaofeng Luo \\ Shaoyang University, Shaoyang, China
}

\begin{abstract}
With the increasing use of smartphones in China, WeChat has become one of the most popular social applications. With its powerful functions, WeChat not only implements social features for its users but also provides a new way to fulfill mobile learning (M-learning), which is a form of distance education with the use of mobile devices. After analyzing M-learning models and WeChat's features, this paper attempts to integrate WeChat's interactive functions to construct a WeChat teaching platform under the guidance of constructive theory. The WeChat teaching platform was constructed based on WeChat's multiple functions and with the support of wireless network technology. It can help to increase the interaction between students and teachers, because such interaction makes achieving ubiquitous learning for university students feasible. This empirical study proved that the new model is feasible and effective in facilitating interaction in translation teaching and in developing the students' translation competence.
\end{abstract}

Index Terms-Interactive teaching, M-learning, WeChat teaching platform

\section{INTRODUCTION}

The $37^{\text {th }}$ statistical report of the China Internet Network Information Center indicated that the number of mobile Internet users in China reached 620 million as of December 2015. The utilization ratio of mobile phones as a means to access the Internet reached $90.1 \%$. Moreover, the network infrastructure has improved, and the mobile network speed has significantly increased, thereby increasing the $3 \mathrm{G} / 4 \mathrm{G}$ network usage rate. Thus, wireless network coverage has significantly improved; Wi-Fi Internet usage has reached $91.8 \%$ [1]. With the rapid development of wireless network technology and mobile devices, people can use smartphones to learn anytime and anywhere. As a mobile application with more than 700 million users in the world, WeChat has given rise to a new form of social life and has also provided a new way of learning. As a result of its popularity and powerful functions, WeChat has been applied to the field of mobile learning (M-learning) in recent years. How to effectively explore WeChat's features and construct a WeChat-based teaching platform is the key issue for the application of WeChat in M-learning.

\section{STATE OF ART}

M-learning is a new way of learning in the information age. Several experts have offered different definitions of M-learning. According to Crompton, M-learning is "learning across multiple contexts, through social and content interactions, using personal electronic devices" [2]. Cha- bra defines M-learning as the ability to learn anytime, anywhere, and on any device [3]. Dye pointed out that $\mathrm{M}$ learning is learning that can take place anytime and anywhere with the help of a mobile computer device. The device must be capable of presenting learning content and providing wireless two-way communication between teacher(s) and student(s). Typically, an educational organization administers both the course content and the communication services [4-6]. Although different scholars provided different definitions of M-learning, their definitions have one thing in common: the emphasis on learning anytime and anywhere. The study of M-learning started from Carnegie Mellon University's Wireless Andrew Project in 1994. In 2000, Dr. Keegan delivered a speech entitled "From distance learning to e-learning and then to mobile learning," which introduced the concept of Mlearning in China [7-8]. Several experts believe that distance learning and e-learning are giving way to $\mathrm{M}$ learning. Gui Qingyang even predicts that M-learning is the future of Chinese language learning [9].

M-learning also creates learning opportunities that are significantly different from those provided by e-learning (on a desktop) or paper-based distance learning. Kristine described the following principal considerations to be taken into account when designing M-learning delivery [10]:

- The urgency of the learning need

- The need for knowledge acquisition

- The mobility of the learning setting

- The interactivity of the learning process

- The situatedness of the instructional activities

- The integration of instructional content

WeChat is a mobile text and voice messaging communication service that was launched by Tencent in China in January 2011. Official data show that WeChat is the world's fastest growing social application with 762 million monthly active users around the world [11-12] WeChat costs less than SMS and MMS. Equipped with ample API interfaces, WeChat provides convenience for third-party developers to design complete M-learning applications. WeChat supports five major operating system platforms, namely, Android, iOS, Symbian, Windows Phone, and BlackBerry, which are the top five global smartphone operating systems that account for $99.4 \%$ of the market share according to IDC latest statistics.

WeChat provides text messaging, hold-to-talk voice messaging, broadcast (one-to-many) messaging, video conferencing, video gaming, photo and video sharing, and location sharing. WeChat is an efficient, multi-modal, integrated mobile interactive platform. A variety of inter- 
active modes allows more flexibility in interaction. In addition, compared with MicroBlog, mobile QQ, and other instant messaging software, WeChat pays more attention to the development of different functional features. WeChat's main features are shown in Table 1.

WeChat integrated the functions of SMS, phone calls, e-mail, MicroBlog, and forums, thereby constituting an efficient multi-modal and interactive platform. With its convenience and good user experience, WeChat has become the most popular mobile communications application among young people. The features' advantages provide a platform for building an interactive mobile translation teaching model.

\section{METhODOLOGY}

M-learning is different from the traditional way of learning. M-learning extends the learning environment from the classroom to outside the classroom. The roles of teachers and students are also changing. Therefore, constructivism was introduced as the theoretical basis of the study. Afterwards, the author constructed a WeChat teaching platform for a translation class. This platform realized various ways of interaction between students and teachers, and promoted learning efficiency.

\section{A. Theoretical basis}

With the development of constructive theory in the educational field, a concept that has become generally accepted is that knowledge is constructed by learners rather than being simply transmitted to them by their teachers. Kiraly depicted translation in terms of a double bind: as an internal cognitive process and as an external social phenomenon [13]. According to constructivism, students are the subject of cognitive activities, not passive recipients of external stimuli [14]. The learning process occurs in the learners' interaction with the environment (including learning resources, teachers, students, and media). Kafai and Resnik emphasized the importance of studentcentered learning, which focuses on the students' autonomy [15]. Teachers act as the main organizer and assistant in the entire learning process. Therefore, interactive translation teaching attaches importance to cooperation and consultation between teachers and students in the translation teaching process, thereby emphasizing the students' interaction with the learning environment to enable selfconstruction of translation skills. As teaching organizers, teachers need to design teaching activities to guide and encourage students to interact with classmates, teachers, and learning resources.

\section{B. WeChat teaching platform in interactive translation teaching}

Under the guidance of constructivist theory, we developed a WeChat-based interactive translation mobile teaching platform (referred to as "WeChat teaching platform") (Fig. 1). In the WeChat teaching platform, teachers share translation materials on a WeChat public account and open platform. Students send their translated texts to the WeChat open platform, and teachers and classmates can comment on the translation after they read the translated texts. Group chat provides a good opportunity for students' collaborative study, whereas private chat offers individual communication. Through the WeChat teaching platform, students and teachers achieve full interaction.
In the WeChat teaching platform, WeChat public accounts play an important role in sharing learning resources. The push mode allows WeChat public accounts to push information to subscribers; therefore, users who are interested in a certain field obtain relevant information automatically. The advantages of the push mode are instantaneity, automaticity, and accuracy. Through the message interface, WeChat public accounts send information, pictures, texts, videos and exercises to the server. The server then delivers these materials to WeChat users. After registering a WeChat public account, teachers can push different types of materials to users (Fig. 2).

TABLE I.

WECHAT'S MAIN FEATURES AND ITS FUNCTIONS

\begin{tabular}{|l|l|}
\hline \multicolumn{1}{|c|}{ Features } & \multicolumn{1}{c|}{ Functions } \\
\hline Voice Chat & $\begin{array}{l}\text { Record and send voice messages by holding the } \\
\text { "hold to talk" button }\end{array}$ \\
\hline Group Chat & $\begin{array}{l}\text { Start group chat by selecting the contacts you } \\
\text { want to add }\end{array}$ \\
\hline Moments & Share your photos or words with your friends \\
\hline Free Call & Invite friends to a free voice call \\
\hline Video Call & Talk to your friends face to face \\
\hline Broadcast Message & Deliver a message to many recipients at once \\
\hline Friend Radar & $\begin{array}{l}\text { Add friends who are using the feature to your } \\
\text { contact list }\end{array}$ \\
\hline $\begin{array}{l}\text { WeChat group QR } \\
\text { code }\end{array}$ & $\begin{array}{l}\text { Invite your friends to a WeChat group chat via } \\
\text { QR code }\end{array}$ \\
\hline Chat History Backup & $\begin{array}{l}\text { Back up your chat history and restore it to your } \\
\text { new device }\end{array}$ \\
\hline Shake & $\begin{array}{l}\text { Make new friends by shaking your phone to find } \\
\text { people who are shaking their phones as well }\end{array}$ \\
\hline Walkie Talkie & Chat with friends in a Walkie Talkie session \\
\hline
\end{tabular}

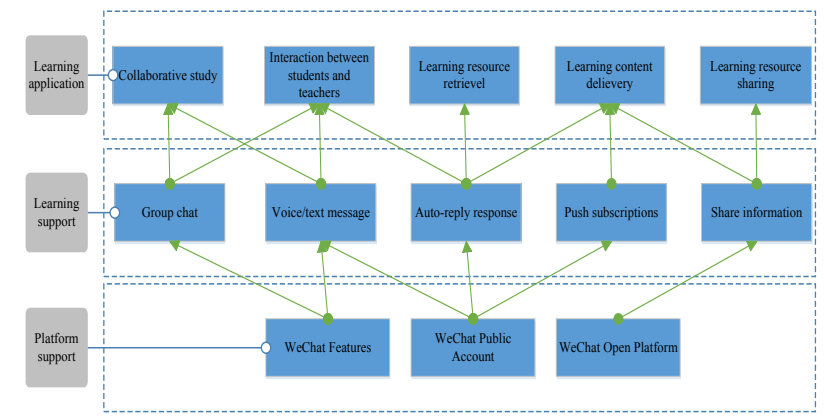

Figure 1. Structure of the WeChat teaching platform

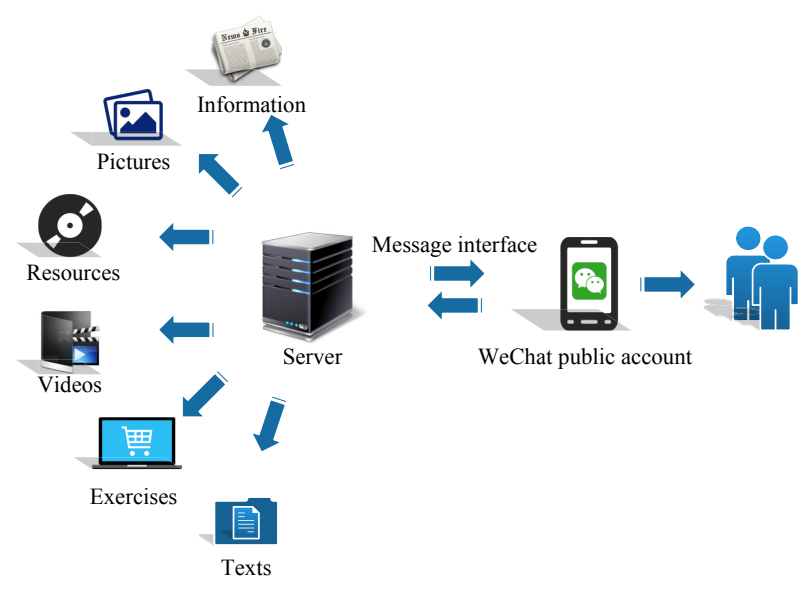

Figure 2. Functions of a WeChat public account 


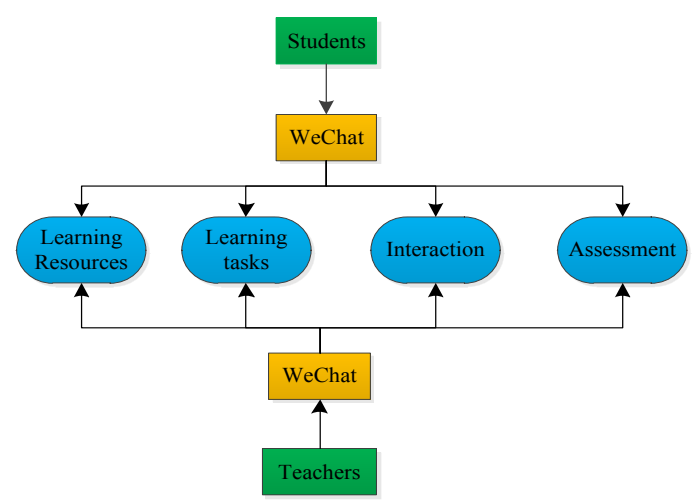

Figure 3. Interactive translation teaching model based on WeChat

By integrating the main interactive function modules of WeChat, we also built an interactive translation teaching model based on WeChat; this model is referred to as "new model" (Fig. 3).

This model emphasizes the students' role and focuses on the students' learning autonomy. The interactions between teachers and students in class and after class are emphasized. Learning resources can be exchanged easily in the WeChat teaching platform. The mobile teaching environment is heuristic, supportive, multi-interactive, and collaborative. Students can discuss translation skills with teachers and classmates, and share translation resources and translated texts in the WeChat teaching platform through the different features of WeChat. Teachers can assess students in the platform. In the WeChat teaching platform, interactions between different forms, construction of translation knowledge, and cultivation of translation competence are achieved.

\section{RESUlt ANALYSIS AND Discussion}

To test if the new model can facilitate interaction in translation teaching, effectively improve the students' translation ability, and gain recognition from students, we applied the new model to a translation course, thus carrying out experimental teaching for a semester.

\section{A. Participants}

Sixty students from the Department of Foreign Languages of Shaoyang University participated in the study. Class A (30 persons) was the experimental class, whereas Class B (30 persons) was the control class. Students from the two classes took translation courses from the same teacher. Pretest results showed no significant difference in the translation ability between the two classes.

\section{B. Data analysis and discussion}

Data were collected in two ways: through the result of experimental teaching and through questionnaires.

Comparative experiment: We conducted a pretest before the experiment and a posttest after the experiment. To ensure the test results' reliability, the pretest and posttest had the same kinds of questions and difficulty. After the tests, three teachers who did not participate in this study gave marks on each test paper in strict accordance with the rating criteria. The average rating of the three marks was used for the final result. Results were analyzed using the statistical software SPSS16.0 to test whether the new model can effectively improve the students' translation ability. The results of the two tests are shown in Table II.
Table II shows that the average pretest scores in classes A and B are similar, thereby indicating that the students' translation abilities are almost at the same level. The average pretest score of class A is slightly lower than that of class B, but an independent sample t test shows no evident difference between the two classes' average pretest scores $(\mathrm{t}=-0.02, \mathrm{P}=0.98>0.05)$. Although the data shows that both the experimental class $\mathrm{A}$ and the control class $\mathrm{B}$ have made progress after taking the learning translation course for one semester, class A's score is comparatively higher than that of class B. After the experimental WeChat-based teaching for a semester, the average posttest score of class A was 80.84 , which is higher than the average pretest score by 8.69 points. The average posttest score of class B was higher than the average pretest score by 2.05 points. The independent sample t test shows a significant difference of the posttest results $(\mathrm{t}=2.05, \mathrm{P}=0.039<0.05)$. The posttest scores of the experimental class were significantly higher than that of the control class. In addition, the paired sample t test showed significant differences in test scores in the experimental classes before and after a semester of experimental teaching $(\mathrm{t}=3.4, \mathrm{P}=0.001<0.05)$. The students' average scores significantly increased. Thus, compared with the traditional teaching model, the new model is more effective in promoting the students' translation ability.

Questionnaire: After the experiment, students in the experimental class received anonymous questionnaires and were required to answer the questions truthfully. The questionnaire consisted of four structural items and an open question, which aimed to highlight the students' perception with regard to the interaction with new teaching models, particularly the WeChat teaching platform (Table III).

TABLE II.

RESULTS OF THE TWO TESTS IN CLASS A AND CLASS B

\begin{tabular}{|c|c|c|c|c|c|c|}
\hline Class & $\begin{array}{c}\text { Number } \\
\text { of Sam- } \\
\text { ples }\end{array}$ & $\begin{array}{c}\text { Average } \\
\text { Pretest } \\
\text { Score }\end{array}$ & $\begin{array}{c}\text { Average } \\
\text { Posttest } \\
\text { Score }\end{array}$ & $\begin{array}{c}\text { Score } \\
\text { Difference }\end{array}$ & $\boldsymbol{t}$ & $\mathbf{P}$ \\
\hline Class A & 30 & 72.15 & 80.84 & +8.69 & 3.40 & 0.001 \\
\hline Class B & 30 & 72.96 & 75.01 & +2.05 & -0.77 & 0.000 \\
\hline
\end{tabular}

TABLE III.

QUESTIONNAIRE REGARDING THE STUDENTS' FEEDBACK

\begin{tabular}{|c|c|c|c|c|}
\hline Questions & \multicolumn{4}{|c|}{ Choices } \\
\hline $\begin{array}{l}\text { Is the WeChat teaching } \\
\text { platform convenient? }\end{array}$ & $\begin{array}{l}\text { A. Very } \\
\text { conve- } \\
\text { nient }\end{array}$ & $\begin{array}{c}\text { B. Conven- } \\
\text { ient }\end{array}$ & $\begin{array}{c}\text { C. Not } \\
\text { convenient }\end{array}$ & $\begin{array}{l}\text { D. Do not } \\
\text { know }\end{array}$ \\
\hline $\begin{array}{l}\text { Do you think that the } \\
\text { WeChat teaching plat- } \\
\text { form is necessary for } \\
\text { translation teaching? }\end{array}$ & $\begin{array}{l}\text { A. Very } \\
\text { neces- } \\
\text { sary }\end{array}$ & $\begin{array}{l}\text { B. Neces- } \\
\text { sary }\end{array}$ & $\begin{array}{l}\text { C. Unnec- } \\
\text { es-sary }\end{array}$ & $\begin{array}{c}\text { D. } \\
\text { Do not } \\
\text { know }\end{array}$ \\
\hline $\begin{array}{l}\text { Do students actively } \\
\text { interact in the WeChat } \\
\text { teaching platform? }\end{array}$ & $\begin{array}{l}\text { A. Very } \\
\text { active }\end{array}$ & B. Active & $\begin{array}{c}\mathrm{C} . \\
\text { Inactive }\end{array}$ & $\begin{array}{c}\text { D. } \\
\text { Do not } \\
\text { know }\end{array}$ \\
\hline $\begin{array}{l}\text { How actively do the } \\
\text { students interact in the } \\
\text { WeChat teaching plat- } \\
\text { form? }\end{array}$ & $\begin{array}{l}\text { A. Very } \\
\text { useful }\end{array}$ & B. Useful & $\begin{array}{c}\text { C. } \\
\text { Not useful }\end{array}$ & $\begin{array}{c}\text { D. } \\
\text { Do not } \\
\text { know }\end{array}$ \\
\hline $\begin{array}{l}\text { What is your evaluation } \\
\text { and suggestion with } \\
\text { regard to the new mod- } \\
\text { el? }\end{array}$ & & & & \\
\hline
\end{tabular}


In this survey, a total of 30 questionnaires were distributed to the students of the experimental class A. A total of 30 questionnaires were returned, but only 29 of the questionnaires were valid.

When asked about the convenience of the WeChat teaching platform, $41.3 \%$ of the students think that the platform is very convenient, and $51.7 \%$ think that the platform is convenient. Only one student thinks that such a platform is not convenient, and one student does not know whether the platform offers convenience or not. Most students stated that the WeChat teaching platform is easy to access and operate, especially the voice messaging function, which is particularly convenient for them (Fig. 4).

With regard to the question "Do you think that the WeChat teaching platform is necessary for translation teaching?" $27.6 \%$ believe that the platform is very necessary, $62.1 \%$ think that the platform is necessary, $3.4 \%$ think that the platform is unnecessary, and $6.9 \%$ do not know whether the platform is necessary for them (Fig. 5).

On the question about how actively do the students interact in the WeChat teaching platform, 34.5\% of the students confirmed that they are very active in the platform, $48.3 \%$ stated that they are active, $10.3 \%$ answered that they are not active, and $6.9 \%$ answered that they do not know how active they are in the platform. After the class, students and teachers can discuss translation texts and translation skills in the WeChat teaching platform. Most students actively performed in the platform, especially in group chats. The students had good interactions with teachers, classmates, and the external environment. Only a small portion of the students performed negatively in the platform (Fig. 6).

When asked about the platform's usefulness, $86.2 \%$ of students confirmed that the WeChat teaching platform is very useful or useful, $6.9 \%$ of the students denied its usefulness, and $6.9 \%$ students answered that they do not know how useful it would be for them to use such a platform. Most students believe that the platform is useful in helping them improve their translation ability (Fig. 7).

The last item in the questionnaire was an open question. The students were asked to provide an evaluation and suggestion on the new teaching model. Some of the answers are listed as follows:

- Students can access the WeChat teaching platform anytime, especially in accordance to their study availability.

- Students can contact teachers and professors directly.

- Translation materials and texts can be shared immediately and easily.

- Students can simultaneously collaborate on translation.

- More ways of assessment should be applied to the WeChat teaching platform.

- Students could also register WeChat public accounts.

- The student's WeChat account can be linked to the educational administration system to achieve more personalized interactive features.

- The materials shared on the WeChat teaching platform could be more systematic.

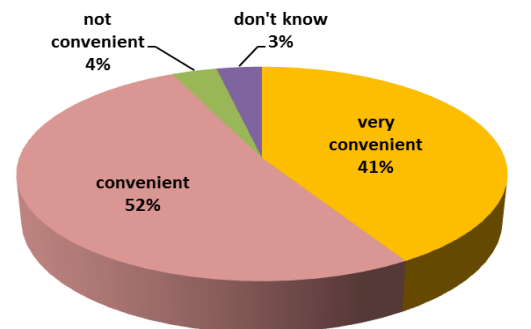

Figure 4. Convenience of the WeChat teaching platform

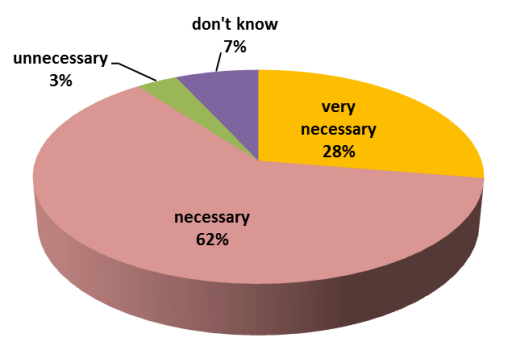

Figure 5. Necessity of the WeChat teaching platform

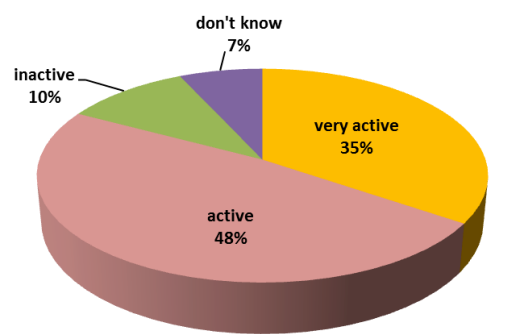

Figure 6. Activeness of students in the platform

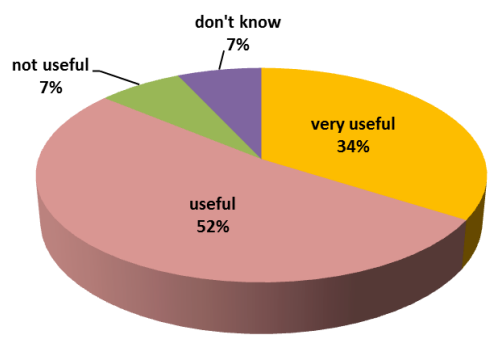

Figure 7. Usefulness of the platform

After analyzing the questionnaire's results, we can conclude that the WeChat teaching platform is helpful in increasing the students' interest in translation learning. Students are willing to interact with teachers in the WeChat teaching platform to create a friendly learning environment and receive immediate feedback.

\section{Research limitation}

This research has some deficiencies. Only two classes were selected as the research subjects, which is considered a small sample. The construction of any model needs to be improved through considerable research and practice. Therefore, more practice will be conducted, and more samples will be involved in future research. Moreover, the study of M-learning is in its early stage in China. Several issues need to be considered and studied further. 


\section{SHORT PAPER}

\section{APPLiCATION OF WeChat TEACHING PlatForm In INTERACTIVE TRANSLATION TEACHING}

\section{CONCLUSIONS}

To introduce interactive M-learning to translation teaching, a WeChat teaching platform was constructed and implemented. The WeChat teaching platform offers new opportunities to achieve full interaction with other users on a multimedia application. Texts, pictures, voice messages, and videos can be shared on public accounts and the open platform. Students can access these resources anytime and anywhere, thereby providing them with great learning autonomy. The new teaching model extends teaching from the classroom to outside the classroom. The new model combines traditional instructional teaching and autonomous learning, thus emphasizing the teacher's lead role and the student's centered role in the process. This study can meet the demand for autonomous learning with the use of the WeChat teaching platform. However, the new teaching model is still in its early stage and needs to be developed further and tested by more empirical studies.

\section{REFERENCES}

[1] CNNIC, "Statistical Report on Internet Development in China," retrieved from

http://www1.cnnic.cn/IDR/ReportDownloads/201604/P02016041 9390562421055.pdf

[2] H. Crompton, "A historical overview of mobile learning: Toward learner-centered education.” In Z. L. Berge \& L. Y. Muilenburg (Eds.) Handbook of mobile learning. Florence, KY: Routledge. 2013, pp. 3-14

[3] Mohamed Sarrab, "M-learning in education: Omani Undergraduate students perspective," Procedia - Social and Behavioral Sciences, 2015, vol.176, pp. 834 - 839 http://dx.doi.org/10.1016/ j.sbspro.2015.01.547

[4] A. Dye, et al, "Mobile education: a glance at the future," retrieved from http://www.nettskolen.com/forskning/mobile education.pdf.

[5] Wang Youmei, "Research Status and Future Trends of China's Mobile Learning in Recent 20 Years: A Review Based on the Comparison between China and the West," Modern Distance Education Research, 2013, vol. 121, No. 1, pp. 49-55.

[6] G. J. Hwang and C. C. Tsai, "Research Trends in Mobile and Ubiquitous Learning: A Review of Publications in Selected Journals from 2001 to 2010." British Journal of Educational Tech- nology, 2011, vol.4, pp. 65-70. http://dx.doi.org/10.1111/j.14678535.2011.01183.x

[7] Mike Sharples et al, "The Student Learning Organiser." In Mobile Learning: A Handbook for Educators and Trainers, Agnes Kukulska-Hulme, John Traxler Eds. London: Routledge, 2005, pp. $139-149$.

[8] Jenny Wang. et al, "Empowering Mobile Assisted Social ELearning Students' Expectations and Perceptions." World Journal of Education, 2013, vol.2, pp. 59-70. http://dx.doi.org/10.5430/wje.v3n2p59

[9] Gui Qingyang, "M-learning: the Future of Foreign Languages Learning in the Chinese Context," Technology Enhanced Foreign Language Education, 2003, vol. 91, No. 3, pp. 14-17.

[10] Kristine Peters, "M-Learning: Positioning educators for a mobile, connected future. "International Review of Research in Open and Distance Learning, 2007, vol 8, No. 2, pp.29-35. http://dx.doi.org/10.19173/irrodl.v8i2.350

[11] Wang Ping, "Analysis of Support Functions and Design Principles of Mobile Learning Based on WeChat," Journal of Distance Education, 2013, vol.4, No.219, pp. 34-41.

[12] Wang Ping, "Construction and Application of WeChat Mobile Learning Platform," Modern Distance Education Research, 2014, vol.24, No. 5, pp. 88-95.

[13] D. Kiraly, A Social Constructivist Approach to Translator Education: Empowerment from Theory to Practice. Manchester, UK\&Northampton, MA: St Jerome, 2000, pp.5.

[14] D. Olsen, "Constructivist principles of learning and teaching methods." Education. 1999,vol 120, No.2, pp. 347-351.

[15] Y. Kafai and M. Resnik, Constructivism in practice: Designing, thinking and learning in a digital world. Mahwah, NJ: Lawrence Erlhaum Association, 1996.

\section{AUTHORS}

Zijuan Shi is with Department of Foreign Languages, Shaoyang University, Shaoyang, 422000 China (e-mail: zijuanshi@126.com).

Gaofeng Luo is with Key Laboratory of Information Service in Rural Southwestern Hunan, Shaoyang University, Shaoyang, 422000 China (e-mail: gfluo@126.com).

This work is supported by the Research Foundation of the Education Bureau of Hunan Province $(13 \mathrm{C} 853,14 \mathrm{C} 1013)$ and the projects of the Hunan Province Planning of Education Research (XJK014BGD073). Submitted, April, 15, 2016. Published as resubmitted by the authors on August, 5, 2016. 